J. Dairy Sci. 92:6105-6115

doi:10.3168/jds.2009-2213

(c) American Dairy Science Association, 2009.

\title{
Optimal dairy farm adjustments to increased utilization of corn distillers dried grains with solubles ${ }^{1}$
}

\author{
T. M. Schmit, ${ }^{, 2}$ R. N. Boisvert, ${ }^{*}$ D. Enahoro, ${ }^{*}$ and L. E. Chase $\dagger$ \\ *Department of Applied Economics and Management, and \\ †Department of Animal Science, Cornell University, Ithaca, NY 14853
}

\begin{abstract}
The purpose of this paper was to identify effective dairy farm management adjustments related to recent structural changes in agricultural commodity markets because of expanded biofuels production and other market factors. We developed a mathematical programming model of a representative dairy farm in New York State to estimate the effects of changes in the relative prices of important feed components on farm profitability, identify optimal adjustments for on-farm feed production, crop sales, and dairy rations that account for expanded utilization of corn distillers dried grains with solubles (DDGS), and point out potential implications of these adjustments on whole-farm nutrient planning. We mapped out an effective farm-level demand curve for DDGS by varying DDGS prices relative to other primary feed ingredients, which allowed us to compare DDGS utilization at alternative market conditions. Had the relative prices of major feed ingredients remained at their historical averages, our results suggest that there is only modest potential for feeding DDGS through supplementation in rations for dry cows and heifers as a substitute for soybean meal. However, the relatively lower DDGS prices experienced in 2008 imply an expanded optimal use of DDGS to include rations for lactating cows at $10 \%$ of the total mixed ration. Despite these expanded opportunities for DDGS at lower prices, the effects on farm net returns were modest. The most important considerations are perhaps those related to changes in the phosphorus $(\mathrm{P})$ levels in the dairy waste. We showed that including moderate levels of DDGS (10\%) in rations for lactating cows did not significantly increase $\mathrm{P}$ excretion. However, if the ra-
\end{abstract}

Received March 14, 2009.

Accepted August 11, 2009.

${ }^{1}$ This material is based upon work supported by USDA Cooperative State Research, Education, and Extension Service Hatch funds NYC127463 and NYC-127429. Although the research described in the article has been funded in part by USDA Cooperative State Research, Education and Extension Service Hatch funds, it has not been subjected to USDA review and, therefore, does not necessarily reflect the views of the Agency, and no official endorsement should be inferred.

${ }^{2}$ Corresponding author: tms1@cornell.edu tions for dry cows and heifers were supplemented with DDGS, P excretion did increase, resulting in sizable increases of plant-available phosphorus applied to cropland well beyond crop nutrient requirements. Although our results show that it is economically optimal for the dairy producer to incorporate DDGS into these rations, some operations will be unable to accommodate the additional $\mathrm{P}$ because of existing nutrient management recommendations, soil $\mathrm{P}$ status, and the number of acres available for manure spreading.

Key words: biofuel, distillers dried grains with solubles, dairy farm returns, nutrient management

\section{INTRODUCTION}

The expansion of the US biofuels industry has contributed to the recent, rather abrupt changes in agricultural commodity markets. State and federal policies promoting biofuels production have led to expanded dedicated biofuels crop acreage that has related effects on both cropping and livestock production decisions because of changes in the prices of grains and related livestock feed commodities. These increased demands for grains and oilseeds as well as those due to continuing world agricultural commodity consumption exceeding production growth have led to increased price volatility in the short run and are likely to continue to put pressure on the overall level of commodity prices in the longer term.

These changes have substantially different implications for crop and livestock producers across the country. In states such as New York, for example, higher grain prices provide some opportunities to expand cash crop production. In contrast, the dramatic increase in commodity prices, particularly corn, between 2006 and 2007, translated into an estimated $18 \%$ increase in the costs of dairy feed in the Northeast, and an additional $20 \%$ by mid-2008 (NASS, 1991-2009). To mitigate the effects of these higher feed costs on production levels and profitability, many feed manufacturers and dairy producers will shift to lower cost alternatives.

Because corn distillers dried grains with solubles (DDGS) is a by-product of dry grind ethanol produc- 
tion, strong growth in ethanol production over the past few years also implies greater supplies of this livestock feed product. In a recent study that regressed the cost of complete dairy feeds in the Northeast as reported by the USDA on the prices of major feed ingredients, Schmit et al. (2009) estimated that each $\$ 1 / \mathrm{t}$ increase in the price of corn translates into a $\$ 0.65 / \mathrm{t}$ increase in the cost of dairy feed when evaluated at 2007 prices. This cost increase falls to $\$ 0.54 / \mathrm{t}$ if the expected future growth in DDGS supply results in lower DDGS prices relative to corn. Although these results are informative, they are unlikely to reflect any dramatic change in ration formulations if price differentials of feed ingredients change markedly from historic levels.

Of course, the use of DDGS in dairy rations should not be made independently from other whole-farm planning decisions. For example, dairy producers may make other management adjustments, including the proportional use of alternative forages that are consistent with growing a larger portion of total dairy feed. The extent to which this is possible depends on the nature of a farmer's land resources, along with changes in relative prices. In addition, management adjustments may also be in response to changes in the nutrient content of animal waste when rations are adjusted by using alternative and less expensive feed ingredients.

The purpose of this paper was to identify effective management adjustments to these recent structural changes in commodity markets. To accomplish this objective we 1) estimated the effects of increased feed prices and changes in the relative prices of important dairy feed components on whole-farm profitability; 2) identified optimal adjustments for on-farm feed production, feed purchases, crop sales, and dairy rations that account explicitly for expanded utilization of DDGS feedstocks; and 3) highlighted potential implications of these production management adjustments on wholefarm nutrient planning.

To estimate these effects, we developed a mathematical programming model of a representative dairy farm in New York State. To account for recent structural changes in commodity markets, our initial analysis reflected the most recent (2008) relative price differences among major dairy feed ingredients. However, because there is a great deal of uncertainty about the future supply of biofuel-related feedstocks, such as DDGS, and their prices, we mapped out an effective farm-level demand curve for DDGS by varying their prices relative to those for other major feed ingredients.

We extended this model through the inclusion of new components that link bio-energy feedstocks, feed prices, and nutrient loadings. These linkages were established through the use of the CPM-Dairy program to generate alternative dairy TMR. This program, a joint effort of Cornell University, University of Pennsylvania Veterinary College, and the Miner Institute, has biology similar to the Cornell Net Carbohydrate and Protein System (CNCPS) model (Fox et al., 2004). Because there is some concern that the level of phosphorus in dairy waste may increase through increased utilization of DDGS feedstocks, we also incorporated into the model information about the nitrogen and phosphorus content of dairy waste that was generated as part of the output from the CPM-Dairy program.

We begin with a discussion of the analytical framework and empirical setting. A short description of the representative dairy farm is incorporated into a discussion of the structure of the mathematical programming model. Throughout the discussion, we describe the sources of the data used to estimate the important coefficients in the empirical model, including the feed ration formulations and crop and livestock production costs and prices. We then go on to discuss the empirical results, summarize the implications for management, and offer some final observations on important issues for future research.

\section{MATERIALS AND METHODS}

The application of mathematical programming methods to farm planning, including the formulation of minimum-cost animal feeds, dates back at least to the 1950s (e.g., Waugh, 1951; Heady and Candler, 1958). Programming methods have also been used extensively to evaluate new opportunities and challenges facing farm operators, including such things as new technologies, alternative cropping methods (e.g., Miranowski, 1984), and policies and management alternatives related to the interface between agricultural production and the environment (e.g., Casler and Jacobs, 1975; Schmit and Knoblauch, 1995; Teague et al., 1995). Based on similar motivations, the programming model of a representative dairy farm in New York State developed here was designed to examine the optimal whole-farm adjustments if the prices of feedstocks such as DDGS were to decrease relative to the prices of other major dairy feed ingredients. In a related analysis, Hadrich et al. (2008) formulated minimum-cost dairy rations that include DDGS and compared the optimal levels of DDGS and other nutrients both with and without consideration of nutrient content of the manure and potential differences in manure disposal costs. However, they did not consider these decisions within a wholefarm context that allows for such things as changes in crop production and feed purchase activities. 


\section{Programming Model Structure for the Representative Farm}

In the programming model, the farmer is assumed to maximize revenue over variable cost. In general notation, it can be represented as

$$
\underset{X_{j}}{\operatorname{Max}} Z=\sum_{j=1}^{n} c_{j} X_{j}
$$

subject to

$$
\begin{gathered}
\sum_{j=1}^{n} a_{i j} X_{j} \leq b_{i}(i=1, \cdots, m), \\
X_{j} \geq 0(j=1, \cdots, m),
\end{gathered}
$$

where $X_{j}$ is the level of the $j$ th farm activity, including such things as the production, sale, or purchase of a product or input and the transfer of products or inputs across production processes; $c_{j}$ is the estimated gross margin, price, or per unit cost of activity $j ; a_{i j}$ is the amount of resource $i$ needed to produce a unit of activity $j$; and the availability of resource $i$ is given by $b_{i}$. The structure of the model was designed to facilitate an investigation of the potential uses of DDGS in dairy feed under alternative assumptions about the relative prices between DDGS and other feed ingredients and the cost of grown feed. A detailed description of the programming activities along with an algebraic formulation of the 27 sets of model constraints can be found in Schmit et al. (2008), and the key components to the model are discussed below.

\section{The Farm Setting}

The representative farm setting on which the programming model was based is similar to that in Schmit and Knoblauch (1995). For this analysis, we assumed that the farm was a 250-cow dairy, with characteristics similar to equivalently sized dairy farms in central New York State participating in Cornell's Dairy Farm Business Summary (e.g., Knoblauch et al., 2008a). It was assumed that replacements were raised on the farm and that cull animals were sold. Separate constraints in the model accounted for the appropriate physical relationships among the numbers of lactating cows and the numbers of dry cows and heifers.

The farm was assumed to have 251 ha of cropland; about one-tenth of the land was of high quality, another quarter of the land was of relatively low quality, and the remaining two-thirds was of an average quality for the region. Land quality was based primarily on the land capability class and potential corn silage yields on a DM basis (adjusted for field and storage losses) of 11.0, 11.9, and $13.2 \mathrm{t} / \mathrm{ha}$, for low, average, and high quality land, respectively. The proportions of land in the 3 land classes were derived from survey data on cropland in farms used by Boisvert et al. (1997). Specific constraints in the model ensured that crop production on any of the 3 land classes did not exceed the amount of land available.

Corn grain, alfalfa, and orchardgrass could be grown for use as feed or sold as cash crops. These crops could also be purchased for feed. In addition, corn silage could be grown, but through several constraints in the model, it was restricted to on-farm use with no opportunity for sale. Other feed ingredients utilized within the livestock TMR were assumed to be purchased at 2008 average farm-level prices. Crop rotations common in New York State were assumed to be followed. Specifically, although alfalfa and orchardgrass could be grown continuously, corn could be grown on the same land in at most 4 out of $8 \mathrm{yr}$, effectively limiting corn hectares to at most one-half of total crop hectares available. The programming model contained specific constraints that ensured these rotations were followed.

\section{Defining the Programming Activities}

On average, purchased feed costs account for over $35 \%$ of the operating cost of milk production on dairy farms in New York State (Knoblauch et al., 2008b). Furthermore, it is evident from Table 1 that the price of milk and the prices for major feed ingredients in 2008 were well above the average levels over the past 17 yr. The most dramatic differences were seen in soybean meal and corn grain, where average 2008 prices were 80 and $90 \%$ higher, respectively, than their 1991 to 2007 averages. In contrast, prices for orchardgrass, DDGS, and alfalfa were only 20,30, and 50\% higher, respectively.

For these reasons, the programming activities and the structure of the programming model were designed to facilitate an understanding of how relative prices among feed ingredients affect the composition of the final TMR, the amounts of particular feeds purchased or grown, and thus the nature of the optimal programming solutions. This was accomplished by defining separate programming activities that distinguished between the production of agricultural commodities and their use (e.g., for sale, in the case of milk and cull cows and calves, and for on-farm use as feed or for sale, in the case of grown crops). The model also had separate activities for the purchase of all feed ingredients. We also isolated in separate activities the purchase of several types of la- 
Table 1. Historical distributions in milk $(\$ / \mathrm{kg})$ and major purchased feed prices $(\$ / \mathrm{t})$

\begin{tabular}{llccccc}
\hline Year $^{1}$ & Milk & Alfalfa & Orchardgrass & Corn grain & DDGS $^{2}$ & Soybean meal \\
\hline $2008(\mathrm{~A})$ & 0.43 & 230 & 141 & 260 & 155 & 664 \\
1991-2007 (B) & 0.33 & 151 & 120 & 135 & 135 & 372 \\
Ratio A:B & 1.3 & 1.5 & 1.2 & 1.9 & 1.3 & 1.8 \\
\hline
\end{tabular}

${ }^{1}$ With the exception of DDGS (St. Lawrence, IN), all prices reflect annual average New York prices (NASS, 1991-2009). The 1991 to 2007 prices are annual averages across all years. Feed prices are expressed on a DM basis.

${ }^{2}$ DDGS8 $=$ corn distillers dried grains with soluble, $8 \%$ fat (DM).

bor, fertilizers, and fuels. The sales and purchase prices for milk, feed ingredients, labor, fertilizer, and fuel are reflected in the objective function coefficients for the respective sale and purchase activities.

By adopting these conventions, the model could accommodate the sales and purchases of commodities and inputs from different sources and allocate them internally within the model to the variety of potential uses. This was accomplished with a series of accounting constraints for the sales of milk and cull animals and crops, and the purchase or use of grown feed and other inputs.

Within this structure, only the other variable costs are reflected in the objective function coefficients of the associated livestock (e.g., breeding costs, veterinary services, utilities, supplies) and crop (e.g., seed, soil testing, lime, repair and maintenance, storage, supplies) activities. The costs for crops could differ depending on the land productivity classes on which they are grown, but individually, each of these purchased inputs constituted a small proportion of total production expenses. Because these expenditure items can be purchased in any amounts at the same prices, it is not necessary in the model to place any constraints on the amounts of these inputs that can be purchased. The requirements for these inputs and field and storage losses for crops were adapted from Schmit and Knoblauch (1995). Their costs were updated using indexes of prices paid and received by farmers (NASS, 1991-2009).

\section{Dairy Rations}

To explore the potential use of DDGS in dairy feed, separate programming activities were included in the model for lactating cows, dry cows, and replacement heifers based on alternative balanced TMR (developed using the CPM-Dairy program). Rations were differentiated by forage mix, the type of DDGS fed (by fat content), and the percentage of DDGS included. A lactating cow's TMR included either a 2:1 (CS) or 1:2 (A) corn silage to hay crop silage forage mix (Table 2), whereas the dry cow TMR included a 2:1 corn silage to grass silage ration, and the replacement heifer TMR included a 1:1 corn silage to hay crop silage forage mix (Table 3 ). The DDGS feeds were incorporated into the TMR using either 8 or $12 \%$ fat content (DM) products. Lactating cow TMR included DDGS at 10 or $20 \%$ (DM), whereas DDGS in the TMR for dry cows and replacement heifers was fixed at 13 and $10 \%$ of dietary DM, respectively, as a substitute for soybean meal.

The balanced TMR were based on a $635-\mathrm{kg}$, secondlactation dairy cow with a 60-d dry period and base milk production of $9,684 \mathrm{~kg} / \mathrm{yr}$. The replacement heifer TMR assumed an average weight of $363 \mathrm{~kg}$. The rations were constructed to maintain milk production at the base level. The rations also included limits on allowable changes in DMI, protein, physically effective NDF, and fat, phosphorus (P), and amino acid (methionine and lysine) levels. The approach to TMR formulation proceeded in 2 steps. First, the forage base and level of DDGS (either 8 or $12 \%$ fat) were set at one of the combinations discussed above. Once this was assigned, the CPM-Dairy program was run to optimize the use of other allowable ingredients. To maintain milk production levels, DDGS rations included somewhat higher levels of CP and fat (Table 2).

The full set of alternative ration activities and their components are shown in Table 2 (lactating cows) and Table 3 (dry cows and replacement heifers). There are 10 separate ration activities for the lactating cows, including 2 no-DDGS TMR (CS and A), and 8 DDGS TMR $(2$ forage bases $\times 2$ fat levels $\times 2$ DDGS ration levels). Because only one forage base and one DDGS level are included in the dry cow and heifer TMR, each has 3 separate ration activities. As expected, the quantities of other feed ingredients were adjusted to accommodate the introduction of DDGS into any of the rations, particularly with respect to the levels of corn grain and soybean meal required to meet TMR requirements.

Although the TMR incorporated into the model were limited to 10 and $20 \%$ of DDGS, the programming solutions can reflect a percentage of DDGS anywhere from zero to $20 \%$ if more than one of these activities is in solution. In this case, the effective percentage of DDGS fed was the average of that in the separate TMR, 
Table 2. Feed rations for lactating cows based on type and level of corn distillers dried grains with solubles fed ( $t$ of DM)

\begin{tabular}{|c|c|c|c|c|c|c|c|c|c|c|}
\hline Ingredient (\% CP, \% fat) & \multicolumn{5}{|c|}{ 2:1 corn silage to hay crop silage ${ }^{1}$} & \multicolumn{5}{|c|}{ 1:2 corn silage to hay crop silage ${ }^{1}$} \\
\hline Corn silage $(8.0,3.2)$ & 2.79 & 2.67 & 2.63 & 2.63 & 2.63 & 1.27 & 1.27 & 1.28 & 1.27 & 1.27 \\
\hline Corn grain $(9.0,4.2)$ & 0.87 & 0.56 & 0.04 & 0.61 & 0.03 & 1.53 & 1.12 & 0.59 & 1.07 & 0.88 \\
\hline Soyhulls $(12.1,2.6)$ & & 0.55 & 0.55 & 0.52 & 0.55 & & 0.19 & 0.45 & 0.24 & \\
\hline Wheat middlings $(18.4,5.0)$ & 0.34 & 0.12 & & 0.14 & & 0.36 & 0.05 & & 0.06 & \\
\hline Soybean meal $(49.8,7.0)^{4}$ & 0.64 & 0.41 & 0.27 & 0.37 & 0.28 & 0.51 & 0.27 & 0.07 & 0.27 & 0.27 \\
\hline Other $^{5}$ & 0.14 & 0.22 & 0.46 & 0.22 & 0.42 & 0.14 & 0.26 & 0.39 & 0.26 & 0.24 \\
\hline Total, t of DM & 6.15 & 6.51 & 6.57 & 6.42 & 6.47 & 6.39 & 6.40 & 6.66 & 6.39 & 6.51 \\
\hline TMR CP, \% & 16.1 & 16.8 & 19.3 & 16.6 & 18.4 & 16.8 & 18.6 & 19.1 & 18.7 & 19.7 \\
\hline Total manure, $\mathrm{t}$ & 19.15 & 19.37 & 19.78 & 19.26 & 19.23 & 20.32 & 20.32 & 19.78 & 20.32 & 20.70 \\
\hline $\mathrm{N}$ in manure, $\mathrm{kg}$ & 112.39 & 122.03 & 150.63 & 118.76 & 139.35 & 120.23 & 138.34 & 147.58 & 138.64 & 153.13 \\
\hline $\mathrm{P}$ in manure, $\mathrm{kg}$ & 13.57 & 13.69 & 16.56 & 13.60 & 15.70 & 13.87 & 13.87 & 15.73 & 13.87 & 18.14 \\
\hline
\end{tabular}

${ }^{1}$ Rations are on an annual basis and are based on the CPM-Dairy program assuming a 635-kg cow for a 305-d lactation. Ration headings are formatted by primary forage base, DDGS fat percentage, and percentage of DDGS fed on a DM basis, respectively; for example, CS0810 = primary corn silage forage base, $8 \%$ fat DDGS, and 10\% DDGS fed; CS (corn silage) and AL (alfalfa) constitute the 2 rations in which DDGS was not fed.

${ }^{2}$ Mixed hay silage includes both alfalfa and grass hay crops.

${ }^{3}$ DDGS $=$ corn distillers dried grains with solubles.

${ }^{4}$ Soybean meal includes heat-treated soybean meal, SoyPlus (West Central Coop, Ralston, IA).

${ }^{5}$ Other ingredients include blood meal, fat, Mepron (Evonik Deguss GmBH, Hanau-Wolfgang, Germany), and mineral mix.

weighted by the proportion of the herd fed by each TMR appearing in the solution. By including separate activities for dry cows and heifers, we also reflected a broader range of options for feeding DDGS.

\section{Nutrient Management}

The representative farm was assumed to use a 6-mo earthen pit storage system and to spread manure bian- nually. The farm utilized a milking parlor and free-stall building arrangements. Manure entered the storage system daily as a liquid, including milking center effluent. Nutrient content of manure differs based on alternative compositions of the livestock TMR. The CPM-Dairy program was used to estimate the TMR-specific nutrient contents of the manure. These estimates are reported in Tables 2 and 3, and they were incorporated as coefficients in the nutrient constraints of the programming

Table 3. Feed rations for dry cows and replacement heifers based on type and level of corn distillers dried grains with solubles fed (t of DM)

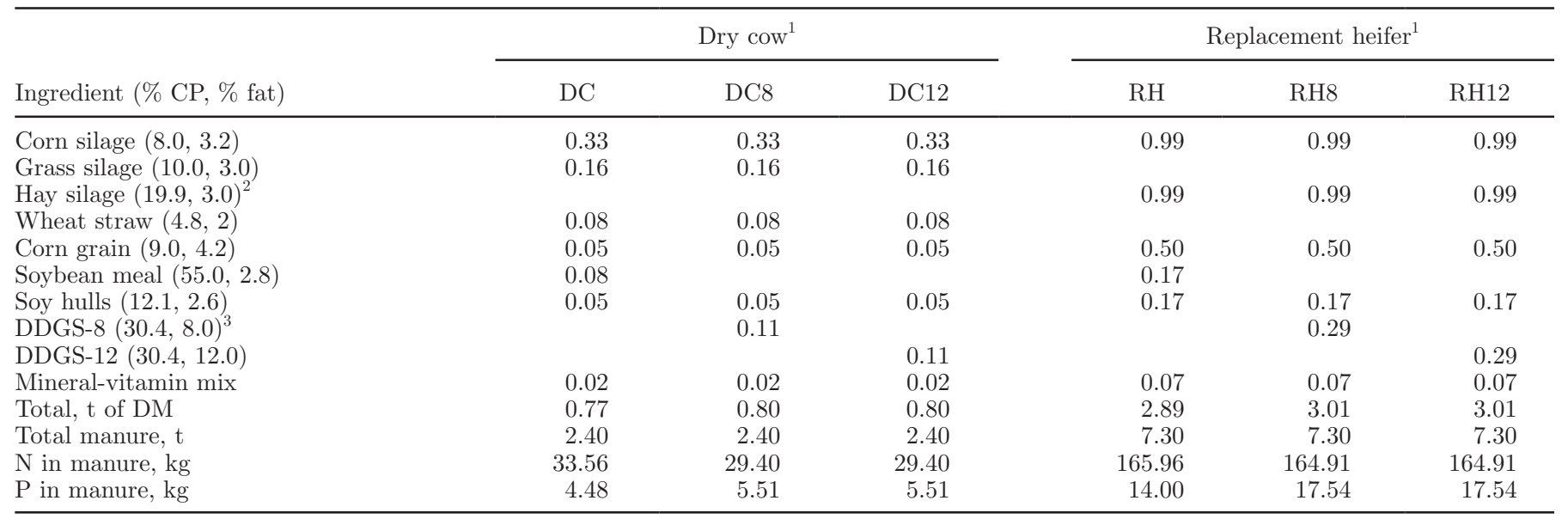

${ }^{1}$ Rations are on an annual basis and are based on the CPM-Dairy program assuming a 635-kg cow for a 60-d dry period and an average $364 \mathrm{~kg}$ replacement heifer for $365 \mathrm{~d}$. Ration headings are formatted by type of DDGS fed. DDGS were included in dry cow rations at approximately $13 \%$ of total DM, heifer rations included DDGS at $10 \%$ of total DM; for example, DC12 = dry cow ration with $12 \%$ fat DDGS, and RH $8=$ replacement heifer ration with $8 \%$ fat DDGS.

${ }^{2}$ Mixed hay silage includes both alfalfa and grass hay crops.

${ }^{3}$ DDGS $=$ corn distillers dried grains with solubles. 
model. As seen in Table 3, the $\mathrm{P}$ excretions for the dry cow and heifer TMR that include DDGS were higher by 23 and 25\%, respectively, relative to the TMR containing no DDGS. The N levels were slightly lower. Because the base TMR (with no DDGS) contained forage levels that exceeded the animals' $\mathrm{P}$ requirements, replacing soybean meal with feed containing a higher level of $\mathrm{P}$ (i.e., DDGS) led to an increase in the excretion of P. For the lactating cow TMR, $\mathrm{N}$ excretions were moderately higher when DDGS was fed at the $10 \%$ level; there was little effect on $\mathrm{P}$ excretion (Table 2). However, both $\mathrm{N}$ and $\mathrm{P}$ excretions were much higher when the TMR included 20\% DDGS (Table 2).

These differences across the TMR for all animal types have potential implications for whole-farm nutrient management planning. In the model, the amounts of these 2 nutrients that appear in the livestock waste were accumulated in separate equations. This structure was necessary so that the amounts of nutrients in the manure could differ depending on the TMR being fed, and so that the nutrients could be appropriately accounted for in meeting crop nutrient requirements through manure spreading. Thus, separate activities were defined in the model for manure application on cropland. The levels of plant-available nutrients per tonne of manure applied also depended on the operating and storage characteristics of the manure handling system. These plant-available nutrients were based on the initial estimates of waste compositions (Tables 2 and 3 ) and then adjusted to account for nutrient losses due to volatilization, denitrification, and so on as described by Schmit and Knoblauch (1995).

Crop nutrient requirements were adjusted in the model to reflect the different crop yields across land class, and nutrient requirements could be met from either purchased fertilizer or manure. All manure produced was applied to the farm's existing land base and was spread at 22.4 or $44.8 \mathrm{t} / \mathrm{ha}$. As with the level of DDGS included in the optimal dairy TMR discussed above, the optimal application rates for manure were determined within the model. Because we assumed that all manure must be applied to the land available for crop production, the nutrient constraints in the model allowed applications of manure to meet or exceed crop requirements. Based on the difference between the levels of plant-available nutrients applied and crop nutrient requirements, we computed the level of excess nutrients applied from each of the model solutions.

\section{RESULTS AND DISCUSSION}

To examine the effects of the most recent changes in agricultural prices on the optimal utilization of DDGS, we began the empirical analysis by solving the model using average 2008 prices as reported in Table 1. However, it remains to be seen if these elevated prices will be sustained in the future, and even if they are, the price of DDGS relative to other major feed ingredients may continue to change, in part depending on the future of the US biofuels industry. Therefore, in the discussion that follows, much of the focus is on how the demand for DDGS at the farm level changes as the price of DDGS is allowed to differ relative to the 2008 levels for other feed prices.

To generate the demand curve for DDGS, we parametrically changed 2 prices in the model, one for DDGS with $8 \%$ fat (DDGS-8) and one for DDGS with $12 \%$ fat (DDGS-12). Both prices were changed in the same proportion. Readily available prices for DDGS do not account for differential fat content. Therefore, to reflect the value of additional fat in DDGS-12, the price of DDGS-8 was lower by the difference in fat content between the 2 rations (i.e., a $40-\mathrm{kg}$ difference per tonne of feed) and valued at the 2008 market price for fat of $\$ 0.49 / \mathrm{kg}$. By proceeding in this systematic fashion, we determined by how much the price of DDGS must increase before it no longer remains a component of the optimal dairy TMR, and by how much the price must decrease before it is included as a component of the dairy TMR at its maximum allowable level.

In this discussion of the empirical results, we focused initially on this derived farm-level demand curve for DDGS. We then proceeded to discuss the nature of the optimal programming solutions that gave rise to the changes in demand for DDGS along the demand curve.

\section{DDGS Demand}

The farm-level demand curve for DDGS as dairy feed (reflecting the combined demand for both DDGS-8 and DDGS-12) derived from our empirical analysis is shown in Figure 1. To emphasize the fact that the demand for DDGS depends on the price of DDGS relative to the prices for other major feeds, the price axis measures the ratio of the price of DDGS for a particular programming solution relative to the 2008 price of corn grain (per tonne of DM). Thus, the point on the price axis of 0.60 reflects the ratio of the 2008 price of DDGS $(\$ 155 / \mathrm{t})$ to the 2008 price of corn grain $(\$ 260 / \mathrm{t})$ from Table 1. Rather than measure the amount of DDGS demanded on the quantity axis, we reported the demand for DDGS in percentage terms - the percentage DDGS in the aggregate dairy TMR (i.e., including lactating cows, dry cows, and replacement heifers) on a DM basis.

This demand curve for DDGS is a typical "step function" characteristic of those generated through linear programming methods (Figure 1). Because of the na- 


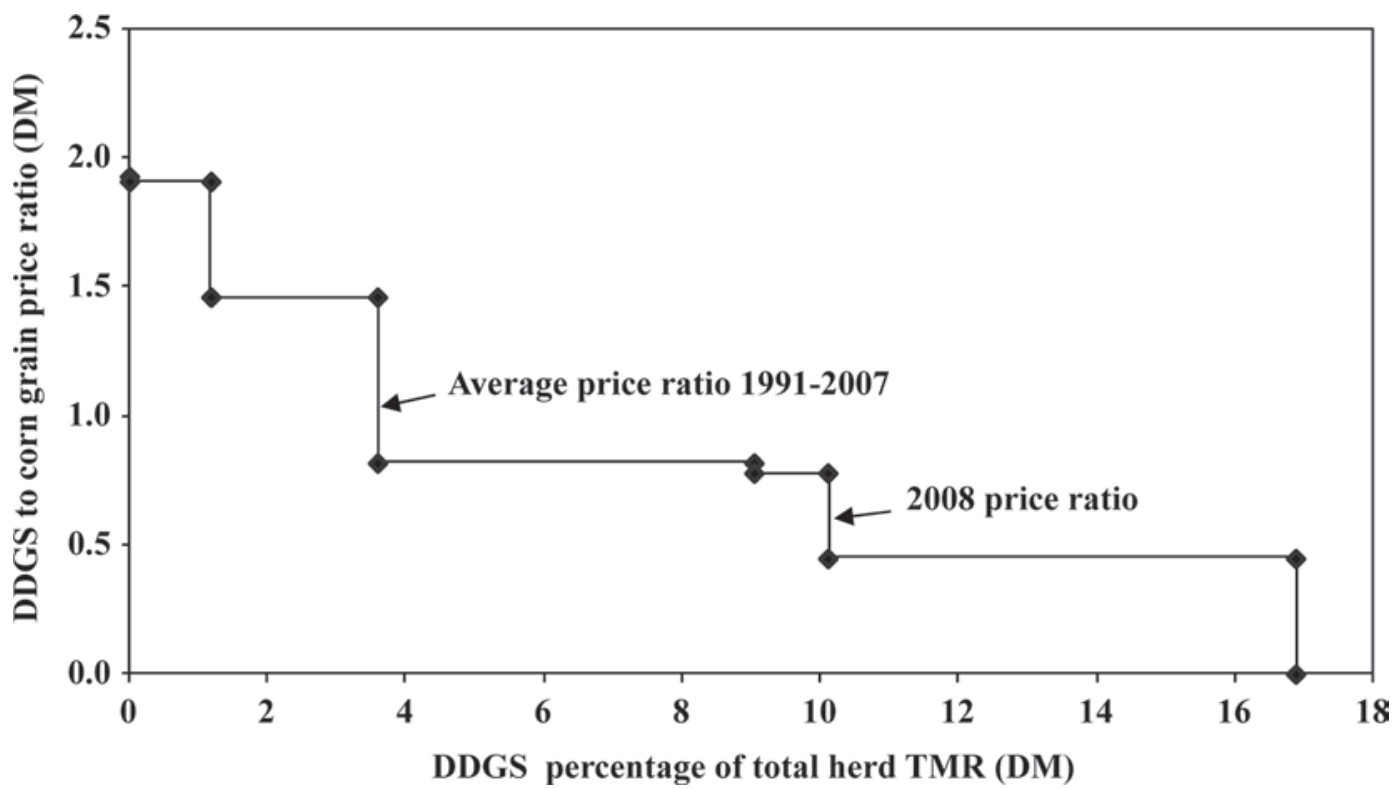

Figure 1. Farm-level demand schedule for corn distillers dried grains with solubles (DDGS), evaluated at 2008 average prices.

ture of the feasible region to any linear programming problem, there is often a range in the price of an input, all else being equal, over which there is no change in the levels of the optimal activities (e.g., Heady and Candler, 1958; Gass, 1985). Therefore, to interpret this discontinuous demand curve, one must distinguish the "risers" (i.e., vertical portions) from the "steps" (i.e., horizontal portions) of this step function.

To make this interpretation, we focused initially on the vertical portions of the demand curve (i.e., the risers in the step function). For example, on this representative farm, the aggregate TMR included just over $10 \%$ DDGS at the 2008 prices (DDGS to corn price ratio $=$ 0.60 ), and this solution will remain optimal as long as the price ratio is below 0.78 and above 0.45 . However, if the price ratio were below 0.45 , then the demand for DDGS would increase, now constituting $16.9 \%$ of the aggregate TMR (i.e., the right-most vertical segment on the demand curve in Figure 1).

In contrast, if we move further up the demand curve, we see that for DDGS to corn price ratios between 0.78 and 0.82 , the demand for DDGS decreases, and the aggregate TMR now contains only 9.1\% DDGS. For price ratios between 0.82 and 1.46, the demand for DDGS would be lower still - reducing the aggregate TMR to only $3.6 \%$ DDGS. This particular segment of the demand curve is of particular interest because it contains the point at which the price ratio of DDGS to corn grain is unity, which is the average ratio observed over the 1991 to 2007 period (Table 1). Thus, had the price of DDGS in 2008 risen by as much as the price of corn grain relative to this 17 -yr average, the optimal use of DDGS would be only about a third of what is optimal at actual 2008 prices. In other words, relative to historical experience and changing market conditions, the optimal use of DDGS would be 6 percentage points higher on a DM basis.

Continuing up the demand curve in Figure 1, it is apparent that as long as the price ratio of DDGS to corn grain is between 1.46 and 1.91, the overall optimal dairy ration would contain only about $1.2 \%$ DDGS. Once the price ratio increases above 1.91, the demand for DDGS decreases to zero. This solution is important as it represents the optimal whole-farm plan if the farmer does not choose to incorporate DDGS into the ration at any price.

The interpretation of all points on the "steps" (horizontal portions) is different; these points are still legitimate points on the demand curve for DDGS. That is, the 2 endpoints along any horizontal portion of the demand curve represent 2 alternative optimal solutions or whole-farm production plans, at the corresponding price ratio of DDGS to corn grain. From the discussion above, we know that once this price ratio exceeds 1.91, then the optimal solution is one where the farmer does not choose to incorporate DDGS into the ration. However, because of the mathematical structure of the linear programming model, it is also true that at exactly a price ratio of 1.91 , the solution in which the TMR contains $1.2 \%$ DDGS is an alternative optimal solution. Furthermore, one can use these 2 solutions to derive other alternative optimal solutions at this price ratio with TMR containing anywhere from 0 to $1.2 \%$ DDGS. These alternative solutions are not automati- 
Table 4. Annual net farm revenues, crop sales, and purchased feed costs, by model solution

\begin{tabular}{|c|c|c|c|c|c|c|c|c|c|c|}
\hline \multirow[b]{2}{*}{ Price ratio $^{1}$} & \multirow{2}{*}{$\begin{array}{c}\text { DDGS in herd } \\
\text { TMR, } \%\end{array}$} & \multirow{2}{*}{$\begin{array}{l}\text { Net farm } \\
\text { revenue, } \$ / \text { cow }\end{array}$} & \multicolumn{2}{|c|}{ Crop sales } & \multicolumn{6}{|c|}{ Purchased feed costs ${ }^{2}$} \\
\hline & & & $\mathrm{ALF}^{3}{ }^{\$} \$ / \mathrm{cow}$ & $\mathrm{CG}, \$ /$ cow & Total, $\$ /$ cow & OG, $\%$ & $\mathrm{CG}, \%$ & DDGS, $\%$ & SBM, $\%$ & Other, $\%$ \\
\hline 1.93 & 0.0 & 1,331 & 318 & 0 & 1,200 & 12 & 6 & 0 & 47 & 35 \\
\hline 1.46 & 3.6 & 1,344 & 318 & 0 & 1,187 & 12 & 6 & 11 & 36 & 35 \\
\hline 0.82 & 9.1 & 1,402 & 326 & 0 & 1,136 & 12 & 0 & 19 & 24 & 45 \\
\hline 0.78 & 10.1 & 1,412 & 327 & 14 & 1,141 & 12 & 0 & 20 & 21 & 47 \\
\hline
\end{tabular}

${ }^{1}$ Ratio of the price of DDGS to the price of corn grain on a per tonne basis (DM). All non-DDGS prices assume 2008 average prices. To compute the implicit DDGS price, multiply the price ratio by $\$ 260 / \mathrm{t}$.

${ }^{2}$ These are total farm feed costs and percentages of total feed costs by ingredient, reported on a per cow basis, but also include purchases for dry cows and heifers. $\mathrm{OG}=$ orchardgrass, $\mathrm{CG}=$ corn grain, DDGS = corn distillers dried grains with solubles (includes both $8 \%$ and $12 \%$ fat types), SBM = soybean meal (includes both regular and heat-treated SBM); Other includes wheat straw, soy hulls, wheat middlings, blood meal, vitamins, and minerals.

${ }^{3} \mathrm{ALF}=$ alfalfa.

${ }^{4}$ This is the solution evaluated at the average 2008 price level for DDGS. The other solutions represent changes in basic solutions as the DDGS price is reduced parametrically from the high $(\$ 499 / \mathrm{t})$ to low $(\$ 116 / \mathrm{t})$.

cally found by solution algorithms to linear programming problems, but they can be calculated easily as convex combinations of the solutions at the 2 endpoints on each step. These convex combinations are essentially weighted averages of the solutions at the 2 endpoints, where the weights sum to unity.

As an example, at a price ratio of 1.91 , one can find an optimal solution containing a TMR with $0.6 \%$ DDGS simply by averaging the solutions at the 2 endpoints (e.g., the weights on the 2 endpoint solutions would be equal to 0.5 ). To construct optimal solutions for TMR with a DDGS percentage between 0.6 and $1.2 \%$, the solution at the endpoint to the right would be assigned a weight greater than 0.5 , whereas the solution at the endpoint to the left would have a weight of less than 0.5 , but the sum of the two would be unity. The opposite would be true in the construction of optimal solutions where the TMR has a DDGS percentage of less than $0.6 \%$.

\section{Net Returns and Management Adjustments}

Based on the nature of this demand curve for DDGS, we need examine only 7 programming solutions. With one exception, these solutions are the ones that correspond to the prices at which the basis solutions to the model change, and as described above, they correspond to the top of each vertical portion on the several steps on the demand curve. The additional solution discussed below is the optimal solution at average 2008 prices (Table 1). For transparency in the discussion, the price ratio of DDGS to corn grain and the corresponding utilization of DDGS in the aggregate herd TMR for each of the solutions are reported in each of the tables that follow.
At all points along the vertical portions of the demand curve, the computed net revenues per cow differ, as one would expect. Over the programming solutions that map out the demand curve for DDGS, net revenue per cow ranges from $\$ 1,331$ to $\$ 1,508$ (Table 4 ). This is a difference of about $13 \%$, but it is important to recall that this range includes a solution in which the price of DDGS is approximately $75 \%$ of the 2008 level (price ratio $=0.45$ ). From the perspective of the current situation, it is perhaps more appropriate to compare the solution containing no DDGS (price ratio $=1.93$ ) with the optimal solution at the 2008 price of DDGS (price ratio $=0.60$ ). With DDGS at 2008 prices, net returns per cow could increase by about $10 \%$ relative to the case where DDGS is not fed.

As the relative prices paid for DDGS decline along the demand curve in Figure 1, there is a general increase in amount of DDGS fed. When DDGS is first purchased as a feed ingredient (i.e., price ratio $=1.91$ ), its use is restricted to that as a substitute for soybean meal in the dry cow TMR by feeding DDGS-8 (Table 5 ). At this price ratio, DDGS accounts for $1.2 \%$ of the total herd TMR (DM) and 5\% of total purchased feed costs (Table 4), even though all lactating cows continue to be fed with a predominantly corn-silage-based TMR that includes no DDGS (CS).

As the relative DDGS price continues to fall, the next change (price ratio $=1.46$ ) is to move all heifers to the DDGS-8 TMR (Table 5). It is important to recall that this would also be the optimal solution had the increase in the price of DDGS kept pace with the price of corn grain in 2008 so that the ratio of the 2 prices would have remained at unity - the average ratio over the past $17 \mathrm{yr}$. In other words, under past average price conditions, the optimal use of DDGS as a feed on this 
Table 5. Percentage of animals fed by ration type

\begin{tabular}{|c|c|c|c|c|c|c|c|c|}
\hline \multirow[b]{3}{*}{ Price ratio $^{1}$} & \multirow{3}{*}{$\begin{array}{c}\text { DDGS in herd } \\
\text { TMR, }{ }^{2} \%\end{array}$} & \multicolumn{7}{|c|}{ Animals fed, ${ }^{3} \%$} \\
\hline & & \multicolumn{3}{|c|}{ Lactating cows } & \multicolumn{2}{|c|}{ Dry cows } & \multicolumn{2}{|c|}{ Heifers } \\
\hline & & $\mathrm{CS}$ & CS1210 & AL0820 & $\mathrm{DC}$ & DC8 & $\mathrm{RH}$ & RH8 \\
\hline 1.93 & 0.0 & 100 & 0 & 0 & 100 & 0 & 100 & 0 \\
\hline 1.91 & 1.2 & 100 & 0 & 0 & 0 & 100 & 100 & 0 \\
\hline 1.46 & 3.6 & 100 & 0 & 0 & 0 & 100 & 0 & 100 \\
\hline 0.82 & 9.1 & 17 & 83 & 0 & 0 & 100 & 0 & 100 \\
\hline 0.78 & 10.1 & 0 & 100 & 0 & 0 & 100 & 0 & 100 \\
\hline $0.60^{4}$ & 10.1 & 0 & 100 & 0 & 0 & 100 & 0 & 100 \\
\hline 0.45 & 16.9 & 0 & 0 & 100 & 0 & 100 & 0 & 100 \\
\hline
\end{tabular}

${ }^{1}$ Ratio of the price of DDGS to the price of corn grain on a per tonne basis (DM). All non-DDGS prices assume 2008 average prices. To compute the implicit DDGS price, multiply the price ratio by $\$ 260 / \mathrm{t}$.

${ }^{2}$ DDGS $=$ corn distillers dried grains with solubles.

${ }^{3} \mathrm{CS}=$ cow TMR, 2:1 corn silage to hay silage forage ratio; CS1210 $=$ cow TMR, 2:1 corn silage to hay silage forage ratio, $12 \%$ fat DDGS included at $10 \%$ level; AL0820 = TMR, 1:2 corn silage to hay silage forage ratio, $8 \%$ fat DDGS included at 20\% level; DC = dry cow TMR; DC8 = DC TMR, $8 \%$ fat DDGS included at $13 \%$ level; RH $=$ replacement heifer TMR; RH8 $=$ RH TMR, $8 \%$ fat DDGS included at $10 \%$ level.

${ }^{4}$ This is the solution evaluated at the average 2008 price level for DDGS. The other solutions represent changes in basic solutions as the DDGS price is reduced parametrically from the high $(\$ 499 / \mathrm{t})$ to low $(\$ 116 / \mathrm{t})$.

representative dairy farm would have been limited to use as a substitute for soybean meal in the TMR for dry cows and young stock.

However, at average 2008 prices, where the price of DDGS is only 0.60 that of corn grain, lactating dairy cows continue to be fed a predominantly corn silage forage base, but now with a TMR containing 10\% DDGS (CS1210 in Table 5). It is only after the ratio of the 2 prices falls by about $25 \%$ (0.45) that there is any additional increase in the use of DDGS. At this low price, it is now optimal to feed lactating cows $20 \%$ DDGS, but with only an 8 percent fat content. In addition, there is a switch to a TMR with a predominantly alfalfa forage base (AL0820 in Table 5). This change in forage base is explained by the rather dramatic decrease in the price ratio of DDGS-8 to corn grain. Because the price of corn grain is now high relative to the price of DDGS, it is now relatively more profitable to sell corn grain. By making the switch to an alfalfa-based ration, less corn is needed for dairy feed, and net farm revenue is maximized through a substantial increase in the sales of corn grain. The increased use of alfalfa for feed is accompanied by a corresponding decrease in sale of alfalfa (Table 4).

Because much of the dairy feed is grown, one might expect changes in crop production as the nature of the aggregate dairy TMR change. For our representative farm situation, the combined influence of market conditions and feeding requirements imply that there is always a maximum number hectares of corn (in the form of silage or grain), as allowed by rotation constraints. However, as the DDGS to corn price ratio falls, land devoted to corn silage begins to be replaced by land in corn grain for sale, primarily because the reduced dependence on corn silage and corn grain in the TMR. Given the assumed levels of alfalfa and orchardgrass prices (Table 1) and feeding requirements, orchardgrass is always purchased, whereas alfalfa is grown for both on-farm feeding and cash crop sales (Table 4).

In the case where no DDGS is fed, the representative farm is a net importer of corn grain to meet total grain feed requirements, where purchased corn grain costs represent about $6 \%$ of total purchased feed costs (Table 4). Specifically, 45 ha of corn grain and 81 ha of corn silage are grown, with all production used for on-farm feeding. However, when the DDGS to corn price ratio falls to 0.78 , reductions in corn silage feed requirements imply a modest shift from corn silage to corn grain acreage and lead to modest sales of corn grain (Table 4). The farm at this point (which is also the solution for when prices are set at their average 2008 levels) becomes a net exporter of corn grain. At relatively low prices for DDGS (price ratio $=0.45$ ), less corn silage is needed in the lactating cow TMR and is instead sold off the farm as corn grain.

\section{Excess Nutrients}

To evaluate the potential use of new dairy feeds such as DDGS, it is also important to examine the implications for whole-farm nutrient management. Although we were careful in our analysis to document changes in the nutrient content of animal wastes, at this stage, the programming model does not include a range of alternatives for disposing of the waste. As stated above, the nutrient requirements for crop production in the 
Table 6. Excess application of nutrients to cropland ${ }^{1}$

\begin{tabular}{lcccccr}
\hline & & \multicolumn{2}{c}{$\begin{array}{c}\text { Hectares with excess } \\
\text { nutrients applied }\end{array}$} & & \multicolumn{2}{c}{$\begin{array}{c}\text { Average nutrient excess } \\
\text { per hectare, } \mathrm{kg} / \mathrm{ha}\end{array}$} \\
\cline { 3 - 4 } \cline { 6 - 7 } Price ratio $^{2}$ & $\begin{array}{c}\text { DDGS in herd } \\
\text { TMR, \% }\end{array}$ & $\mathrm{N}$ & $\mathrm{P}_{2} \mathrm{O}_{5}$ & & $\mathrm{~N}$ & $\mathrm{P}_{2} \mathrm{O}_{5}$ \\
\hline 1.93 & 0 & 97.8 & 44.6 & & 51.2 & 9.9 \\
1.91 & 1.2 & 97.8 & 44.6 & & 50.2 & 11.1 \\
1.46 & 3.6 & 97.8 & 44.6 & & 50.0 & 14.5 \\
0.82 & 9.1 & 98.9 & 45.6 & & 52.7 & 14.3 \\
0.78 & 10.1 & 99.1 & 45.8 & & 53.3 & 14.3 \\
$0.60^{3}$ & 10.1 & 99.1 & 45.8 & & 53.3 & 14.3 \\
0.45 & 16.9 & 125.4 & 51.7 & & 58.3 & 18.7 \\
\hline
\end{tabular}

${ }^{1}$ Excess nutrients are computed as the difference between total plant-available nutrients applied and crop nutrient requirements. All hectares with excess nutrients are corn plantings (silage or grain). Total cropland is 251 ha, of which at most one-half can be in corn.

${ }^{2}$ Ratio of the price of corn distillers dried grains with solubles (DDGS) to the price of corn grain (DM).

${ }^{3}$ This is the solution evaluated at the average 2008 price level for DDGS. The other solutions represent changes in basic solutions as the DDGS price is reduced parametrically from the high $(\$ 499 / \mathrm{t})$ to low $(\$ 116 / \mathrm{t})$.

model may be met from purchased fertilizer, as well as through the spreading of animal waste. Furthermore, we required that all manure produced be applied to the representative farm's cropland and could be spread at 22.4 or $44.8 \mathrm{t} / \mathrm{ha}$ (spreading on hay and grass crops was limited to $22.4 \mathrm{t} / \mathrm{ha}$ ). The optimal application of the manure was determined within the model constraints.

In all solutions, manure was applied at the rate of $22.4 \mathrm{t} /$ ha to all low quality land and to $63 \%$ of the best land; it was applied to the remaining $37 \%$ of the best land at a rate of $44.8 \mathrm{t} / \mathrm{ha}$. Because of the small increase in total manure production in rations with DDGS, the proportion of average quality land on which manure was applied at $44.8 \mathrm{t} /$ ha area increased slightly as the price of DDGS decreased. At the lowest DDGS price, $79 \%$ of the medium-quality land had manure applied at the lower rate, whereas $21 \%$ of the land had manure applied at the higher rate.

Because all manure must be spread on existing cropland, the levels of crop-available $\mathrm{N}$ and $\mathrm{P}_{2} \mathrm{O}_{5}$ applied could potentially exceed the crop requirements. This happened in all solutions on land devoted to corn (silage or grain) production, but the amounts of excess application increased with the percentage of DDGS included in the aggregate herd TMR (Table 6).

To put these results into perspective, we first examined the case when DDGS was not utilized. In this case (top row of Table 6), we computed that excess $\mathrm{N}$ was applied to approximately $78 \%$ (98 ha) of the land in corn production, and excess $\mathrm{P}_{2} \mathrm{O}_{5}$ was applied to about $36 \%$ (45 ha). Put differently, for the assumed farm characteristics, which are representative of common animal to land ratios found on equivalently sized farms in central New York State (Knoblauch et al., 2008a), there are likely nontrivial levels of excess nutrients that must currently be managed appropriately. As farm ani- mal densities decrease (i.e., a reduction in the ratio of animals to available cropland), these levels of existing excess nutrients would be expected to decrease, all else being equal.

Given that the concentrations of $\mathrm{N}$ in the manure for dry cows and heifers decrease when the ration is supplemented with DDGS, any increases in average excess levels of $\mathrm{N}$ relative to this initial solution are observed only in those optimal solutions in which the TMR for lactating cows contains DDGS. In the 2 solutions in which only dry cows and heifers are fed DDGS, the excess $\mathrm{N}$ applied decreases slightly. Thus, the optimal use of DDGS would not exacerbate excess $\mathrm{N}$ levels on cropland for a price ratio of 1.46. Because this solution is also optimal for a price ratio of 1.0, the optimal use of DDGS would not have exacerbated excess $\mathrm{N}$ levels under average market conditions over the period 1991 to 2007 .

However, for the solution consistent with average 2008 prices (price ratio $=0.60$ ), lactating cows are fed a ration of $10 \%$ DDGS. Here, excess N applied increases modestly, about $6 \%$ compared with the no-DDGS solution. Thus, at least at reasonable relative prices for major feed ingredients, it appears that the excess $\mathrm{N}$ on cropland due to manure application can be reasonably managed for optimal increases in the feeding of DDGS. In contrast, if the price of DDGS were to fall relative to other major feed ingredients so that it would be optimal to feed a ration of $20 \%$ DDGS to lactating cows (the solution with $16.9 \%$ in the aggregate TMR, Table 6), this would not be the case. Here, excess $\mathrm{N}$ on cropland due to manure application would be higher than for the no-DDGS solution by $87 \%$ because both the area in excess as well as the level of excess increase.

The patterns of changes in excess $\mathrm{P}_{2} \mathrm{O}_{5}$ applied due to manure application are quite different, particularly 
because of the contributions from both dry cows and heifers. Thus, in the solution when both dry cows and heifers are fed DDGS (a price ratio of 1.46), excess $\mathrm{P}_{2} \mathrm{O}_{5}$ applied to cropland through manure application is $53 \%$ above the level in the optimal solution in which no DDGS is fed (Table 6). The magnitude of this increase is particularly significant, because this solution is also optimal for historical average price conditions.

In contrast, lactating cows are fed a TMR that includes 10\% DDGS in the optimal solution at 2008 average prices (price ratio $=0.60$ ). Here, the average excess $\mathrm{P}_{2} \mathrm{O}_{5}$ per hectare decreases slightly because, in this TMR, there is only a small increase in $\mathrm{P}$ excreted per lactating cow compared with the base ration containing no DDGS (Table 6). However, the situation is different if the price ratio were to decrease to 0.45 , indicating that it is optimal to feed lactating cows $20 \%$ DDGS. In this case average excess $\mathrm{P}_{2} \mathrm{O}_{5}$ applied per hectare increases by an additional $31 \%$. Further, relative to the optimal solution in which no DDGS is fed, excess $\mathrm{P}_{2} \mathrm{O}_{5}$ on cropland due to manure application increases by a total of $154 \%$.

\section{CONCLUSIONS}

We developed a mathematical programming model of a representative New York State dairy farm to identify optimal management adjustments to take advantage of potential increased utilization because of changes in the prices of DDGS as the US bio-energy industry matures. Had current relative prices of major feed ingredients remained at their past 17-yr average, our results suggest that there is extremely modest potential for DDGS serving only as a substitute for soybean meal in the TMR for dry cows and young stock. However, at 2008 prices, DDGS would account for just over $10 \%$ of the aggregate dairy herd TMR on a DM basis at 2008 feed prices. Eventually the farming operation goes from being a net buyer of corn grain to being a modest net seller. However, if the relative price of DDGS (to corn grain) were to fall by $25 \%$ relative to the 2008 level, the farm-level demand for DDGS would be nearly $17 \%$ of the aggregate herd, with a substantial increase in corn grain sales. The most important considerations were perhaps those related to changes in the phosphorus levels in the dairy waste. We showed that including moderate levels of DDGS (10\%) in rations for lactating cows does not significantly increase $\mathrm{P}$ excretion. However, if the rations for dry cows and heifers are supplemented with DDGS, P excretion does increase sizably. Further reductions in the price of DDGS relative to corn grain, which may be particularly feasible in areas near ethanol production facilities, reveal that increased utilization of DDGS in lactating cow TMR (20\%) will put additional burdens on appropriate nutrient management practices to accommodate the higher levels of $\mathrm{P}$ in the manure. Although our results show that it is economically optimal for the dairy producer to incorporate DDGS into these rations, some operations will be unable to accommodate the additional $\mathrm{P}$ because of existing nutrient management recommendations, soil $\mathrm{P}$ status, and the number of acres available for manure spreading. The extent to which these improvements in net return can be sustained depends critically on the identification of low-cost, effective waste management strategies, perhaps including transporting manure off the farm. A careful examination of these issues is a top priority for our continuing research.

\section{REFERENCES}

Boisvert, R. N., T. M. Schmit, and A. Regmi. 1997. Policy implications of ranking distributions of nitrate runoff and leaching from corn production by region and soil productivity. J. Prod. Agric. 10:477-483.

Casler, G., and J. Jacobs. 1975. Economic analysis of reducing phosphorus losses from agricultural production. Pages 169-215 in Nitrogen and Phosphorus: Food Production, Waste and the Environment, K. Porter, ed. Ann Arbor Science Publishers, Ann Arbor, MI

Fox, D., L. Tedeschi, T. Tylutki, J. Russell, M. van Amburgh, L. Chase, A. Pell, and T. Overton. 2004. The Cornell Net Carbohydrate and Protein System model for evaluating herd nutrition and nutrient excretion. Anim. Feed Sci. Technol. 112:29-78.

Gass, S. 1985. Linear Programming: Methods and Applications. 5th ed. McGraw Hill, Inc., New York, NY.

Hadrich, J., C. Wolf, J. Roy Black, and S. Harsh. 2008. Incorporating environmentally compliant manure nutrient disposal costs into least-cost livestock ration formulation. J. Agric. Appl. Econ. 40:287-300.

Heady, E., and W. Candler. 1958. Linear Programming Methods, Iowa State University Press, Ames.

Knoblauch, W. A., G. J. Conneman, and L. D. Putnam. 2008b. Dairyfarm management. Pages 1-15 in New York Economic Handbook 2009, Extension Bulletin 2008-25. Dept. Applied Econ. Mgt., Cornell University, Ithaca, NY.

Knoblauch, W. A., L. D. Putnam, J. Karszes, D. Murray, and R. Moag. 2008a. Dairy farm management business summary, New York State, 2007. Research bulletin 2008-03. Dept. Appl. Econ. Mgt., Cornell University, Ithaca, NY.

Miranowski, J. 1984. Impacts of productivity loss on crop production and management in a dynamic economic model. Am. J. Agric. Econ. 66:61-71.

National Agricultural Statistics Service.1991-2009. Agricultural Prices. Various issues, US Dep. Agric. http://usda.mannlib.cornell.edu/ mannusda/ Accessed Aug. 9, 2009.

Schmit, T., L. Verteramo, and W. G. Tomek. 2009. The implications of growing biofuels demands on northeast livestock feed costs. Agric. Resource Econ. Rev. 38:200-212.

Schmit, T. M., R. N. Boisvert, D. Enahoro, and L. Chase. 2008. Dairy farm management adjustments to biofuels-induced changes in agricultural markets, Working Paper 2008-16, Dept. Appl. Econ. Mgt., Cornell University, Ithaca, NY.

Schmit, T. M., and W. A. Knoblauch. 1995. The impact of nutrient loading restrictions on dairy farm profitability. J. Dairy Sci. 78:1267-1281.

Teague, M. L., D. Bernardo, and H. Mapp. 1995. Farm level economic analysis incorporating stochastic environmental risk assessment. Am. J. Agric. Econ. 77:8-19.

Waugh, F. 1951. The minimum-cost dairy feed. J. Farm Econ. 33:299-310. 